原著

\title{
大学生に於ける結核の疫学的研究
}

第 1 報 琉球大学生の10年間の調査概要

\author{
琉球大学学校医 - 東京医科歯科大学医学部農村厚生医学研究施設 \\ (指導 柳沢文徳教授) \\ 稲 福 盛輝
}

\section{Epidemiological Study of Tuberculosis in College Students (Ryukus)}

Ist Report: An Outline of the Ten-Year Survey of Students at the University of the Ryukyus

\section{Seiki INAFUKU}

School Physician University of the Ryukyus, Naha, Okinarea Medical Institute for Rural Welfare, Tokyo Medical and Dental Unversity'

An epidemiological study of tuberculosis among students at the University of the Ryukyus was tried here on the basis of the data collected from the survey made among 22,391 students at the University of the Ryukyus during the period of 10 years between 1956 and 1965 .

1. There is an indication that the number of pre-college students suffering from tuberculosis has rapidly been increasing. There are more students who suffer from pulmonory tuberculosis than any other type, and most of them have caught the disease at junior and senior high school age. There' is also an indication that the number of students who enter the University of the Ryukyus before recovering from the disease, the number of students who are receiving medication while attending school, and the number of students who leave school for treatment have recently been increasing. I presume that there are surely many patients among applicants for the freshmen at the University of the Ryukyus.

2. The number of student patients gradually decreased during the period of 3 years between 1963 and 1965, and 1965 shows the decrease of $0.66 \%$ since 1963 . The number of student patients who suffered from the intermediate stage of tuberculosis was a 
qurter of the total of student patients in 1963, but in 1965 it rapidly decreased to less than a tenth of the total. Correspondingly there are more student patients suffering from the e'ementary stage of tuberculosis. Each year there are more student patients who needed treatment. However, the number of student patients who needed hospital treatment or had to leave school for treatment gradually decreased. The number of student patients who were infected with tuberculosis before entering the University of the Ryukus is, however, 3 to 4 times as many as that of those who were infected with the disease after entering the University. There is a tendency for more student patients to comefrom rural area than from anywhere else. However, the morbidty rate of tuberculosis among stude: ts from rural area is coming closer to the rate of students from agricultural and fishing villages and towns. Among the total number of students who leave school because of sickness, there are still, however, even though the number is decreasing yearly, more tuberculosis patients than patients of other diseases. Thus, the number of tuberculosis patients at the University of the Rynkyus has been decreasing, and there is an dicationin that a larger number are minor cases of tuberculosis. However, the morbidity rate of tuberculosis among students at this University is still higher than that among Japanese students.

3. Students at the University of the Ryukyus naturally have a positive reaction of tuberculin test since they don't take an inoculation of BCG. The positive reaction rate of a tuberculin test among students at the University of the Ryukyus has gradually keen decreasing. I don't think, however, that this phenomenon nercesarily means the decrease of tuberculosis. Like the morbidity rate of tuberculosis, there is an indication that a positive reaction rate of a tuberculin test among students frcm rural areas has gradually been becoming closer to the rate in agricultural and fishing villages and towns.

\section{はじめに}

沖綶に於ける結核死亡率は, 戦前では全国 でも高率に位する県であつたが，戦後は著し く減少をみせた。しかし未だ十分なる予防対 策や治瘵体制の整借がなされて物らぬし，ま た濃厚感染の機会も多い，従つて，この様な 環境に怙いて大学生に結核の発病がないよう な健康管理の完施が必要である。

琉球大学に特いては他大学々同様に毎年定 期的にッベルクリン（以後ツ反応と称す）接 種・胸部 X 線集団検診を実施して患者の早期 発見，発病の予防やまた 新発病者に対しては その感染源の追及と健康管理に重点を叔いて
いる・しかし，入学前の結核既往歴を有す者の 再発防止，結核羅患中入学者に対する入学後 の経過钼察，また，ツ反応陽性者の発病防止 や陰性者に対する BCG 接種などは今後大学 の結核管理のうえ重要で, 且つ早期に対策せ ねばならない問題であるので，大学生の 結核 の実態をまず把握し，疫学的要因を明らかに する為，10年間に於け琉球大学の結核の 発病 状況などの調査研究を実施したので，その概 要を報告する。

\section{調査対象及び調查方法}

1. 調查対象

1956年〜1965年に至る 10 年間の琉球大学生 
22,391名である.

2 , 調查方法

(1) 入学前結核既往歴反び結核䍜患中入学 者の調査: 大学入試の際に提出する健康診断 書 及び定期身体検查時の問診による。但し， 本調查は 1956年〜1961 年までは調查不十分な 点が認められた。

（2）ッ反応検查：1956 年〜1959 年までは 年 1 回 3 月に実施し, それ以後は年 2 回 3 月, 10月に実施す。使用液は 1963 年までは旧ッへ ルクリン 2 千倍液, 以後PPD液を使用した。ツ 反応判定は結核予防法の施行規則に 規定して いる其準による.なお,本大学生は既往に BCG 未接種の為陽性者はすべて自然陽性者である.

（3）X 線検査： ツ反応陽性者, 疑陽性者, ツ反応末接種に対しては 1961 年までは年 1 回 春期，以後年 2 回春期，秋期に 保健所による 集団間接撮影を行い。疑わしき者は直接撮影 之精密検査によつて患者を決定した。

（4）出身別調查：1964 年に沖縄で実施さ れた結核の 実態調查実施要項による区分法に 準じて，都市，農漁村区分して調査した。

\section{調 查 成 績}

1. 入学前の結核罹患状況

（1）年度別結核䍜患率の推移

図1に示す通り 1956〜1960 年までは 1.5〜 1. $8 \%$ 間の罹患率であるが，1961 年に $1.1 \%$ に 急減している. しかし，1962 年以後急增し，

1. 8 2.5\%間の率を示し 漸次增加の傾向がみ られる。症状別分類では各年度ともに肺結核 が最も多く，1950 年までは $50 \%$ 以上で以後は 65〜75\%と增加して扣り，ついで，肋膜炎が 20〜30\%で，肺外結核は 1959，1960，1965年 に各 1 名づつである.（図 2)

(2) 入学前の結核既往歴及び罹患中入学者 の推移

既往歴の推移は 1956〜1958 年までは 1.4〜 1. 8\%の罹患率で目立つた変動はないが，1959 年〜1961年まで漸次減少の傾向がみられた。

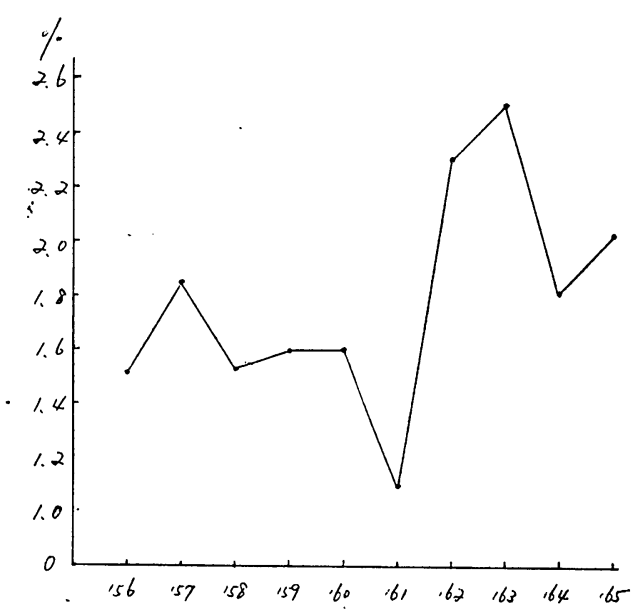

図 1 入学前の結核䍜患率の推移

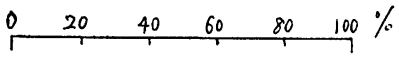

$$
\begin{aligned}
& .56 \text { पIDIIIIIIII } \\
& \text { 159 पIIIIIII } \\
& 158 \text { सIIIIIIIIID } \\
& 159 \text { पIIIIIII - 目 } \\
& \text {.6. VIIIIIIIII } \\
& \text { 16, VIIIIIIIIIII } \\
& 162 \text { VIIIIIIIIID目 } \\
& \text { 63 VIIIIIIIIIID } \\
& 164 \mathrm{MIIIIIIIM} \\
& 165 \text { VIIIIIIIIID目 } \\
& \text { एIII } \square \text { ए } \\
& \text { 肺結核胡脱员肺外結核 }
\end{aligned}
$$

図 2 入学前結核䍜患者の症状別分類

しかし 1962 年以後急増の傾向を示している. 既往歴者の 発病時期は 1964 年を除いては表 1 に示す通り，高校期が最も多く次で，中校期 である。

罹患中の入学者の推移をみると，1962 年ま 
表 1 結核既往歴の発病時期

表 2 䍜患中入学者の入学後の経過状況

\begin{tabular}{|c|c|c|c|c|c|}
\hline \multirow{2}{*}{$\begin{array}{l}\text { 年 } \\
\text { 度 } \\
\text { 別 }\end{array}$} & \multicolumn{4}{|c|}{ 発 病 の 期 間 } & \multirow{2}{*}{ 計 } \\
\hline & $\begin{array}{l}\text { 乳䚮 } \\
\text { 児期 }\end{array}$ & $\begin{array}{c}\text { 小校 } \\
\text { 期 }\end{array}$ & $\begin{array}{c}\text { 中校 } \\
\text { 期 } \\
\end{array}$ & $\begin{array}{c}\text { 高 校 } \\
\text { 期 }\end{array}$ & \\
\hline 1956 & 0 & 0 & 3 & 4 & 7 \\
\hline 1957 & 0 & 1 & 1 & 8 & 10 \\
\hline 1958 & 1 & 1 & 3 & 4 & 9 \\
\hline 1959 & 0 & 0 & 4 & 4 & 8 \\
\hline 1960 & 0 & 1 & 2 & 4 & 7 \\
\hline 1961 & $\dot{0}$ & 2 & 2 & 2 & 6 \\
\hline 1962 & 1 & 0 & 2 & 9 & 12 \\
\hline 1963 & 0 & 0 & 4 & 7 & 11 \\
\hline 1964 & 0 & 2 & 4 & 1 & 7 \\
\hline 1965 & 0 & 1 & 5 & 7 & 13 \\
\hline
\end{tabular}

\begin{tabular}{|c|c|c|c|c|c|c|c|c|c|}
\hline \multirow{3}{*}{$\begin{array}{l}\text { 年 } \\
\text { 度 } \\
\text { 別 }\end{array}$} & \multirow{3}{*}{$\begin{array}{l}\text { 合 } \\
\text { 計 }\end{array}$} & \multicolumn{3}{|c|}{ 要 } & \multicolumn{2}{|l|}{ 医 } & \multicolumn{2}{|l|}{ 療 } & \multirow{3}{*}{$\begin{array}{l}\text { 要 } \\
\text { 観 } \\
\text { 察 }\end{array}$} \\
\hline & & \multicolumn{3}{|c|}{ 休学期間 } & \multicolumn{4}{|c|}{ 服薬通学期間 } & \\
\hline & & $\begin{array}{l}\text { 6r } \\
\text { 月 }\end{array}$ & 1 年 & 計 & 1年 & 2年 & 3年 & 計 & \\
\hline 1956 & 1 & & & & & & & & 1 \\
\hline 1957 & 0 & & & & & & & & \\
\hline 1958 & 0 & & & & & & & & \\
\hline 1959 & 2 & & & & 1 & & & 1 & 1 \\
\hline 1960 & 3 & & & & 1 & & & 1 & 2 \\
\hline 1961 & 1 & & & & 1 & & & 1 & \\
\hline 1962 & 2 & & & & 1 & 1 & & 2 & \\
\hline 1963 & 5 & & 1 & 1 & 1 & 1 & & 2 & 2 \\
\hline 1964 & 8 & & 1 & 1 & 3 & 2 & 1 & 6 & 1 \\
\hline 1965 & 5 & 2 & & 2 & 3 & & & 3 & \\
\hline
\end{tabular}

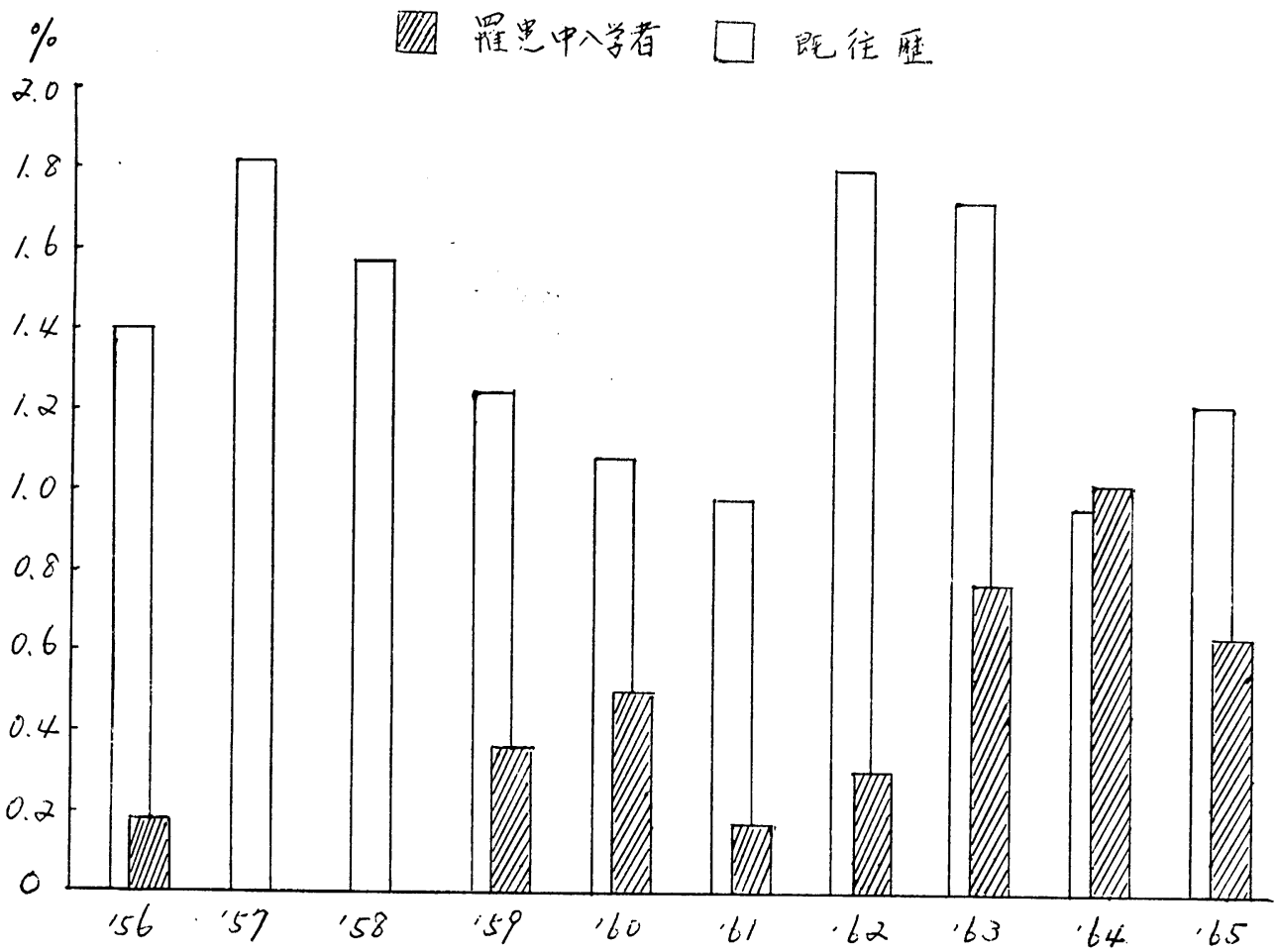

図 3 入学前結核既往歴及罹患中入学者の推移 
では0.5\%以下であつたが，63年以後は急に增 加を示し， 1964 年に至つては既往歴らり高率 を示している．すなわち，漸次增加の傾向の 現象がみられる。（図 3 ）罹患者の入学後の経 過状況は表 2 亿示す通り要医療が 最も多く, その中でも服薬通学（在宅治療）拍で 1 2 年 間服楽している。 また 1963 年以後休学者が多 くなる傾向がみられる。

2. 在学生の結核羅患状況

A 在学生の結核䍜患の実態（1963～1965）

(1) 結核罹患率の状況

1963 1965 年の 3 年間に於ける在学生の結 核羅患率は表 3 に示す通り 1963 年 $(2.21 \%)$ 1964 年 $(1.98 \%)$ 1965年 (1.55\%) と溸次減 少の傾向を示した． 結核総数に 対する新発病 者の占める率は1963年 $29.1 \% ， 1964$ 年 $18.9 \%$ ， 1965年 $25 \%$ を占めて拈り各年度とも旧結核患 者が，70〜80\%の高率を占めている。（図 4)

（2）症状別分類からみた䍜患状況

各年度とも軽症が最も多く次で中等症であ り，又肋膜炎と肺外結核とは 1963 年では肺外 結核が多いが，1964 年，1965 年は全く同率を 示している，軽症は 1963年 (56.4\%) 1964年 (54.7\%)で1/2以上を占めているが，1965年は

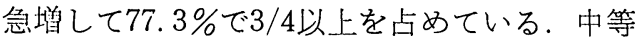
症は 1963 年に $25.5 \% ， 1964$ 年 $22.6 \%$ で約 $1 / 4$ を占めているが 1965年は激減して 1/10以下の $9.1 \%$ である. 肋膜炎は 1964 年 $11.3 \%$ で最も 多く1963年,1965年は大差がない，肺外結核は 1963年 1964 年は大差なく約 $11 \%$ 占めている が，1965年は6.8\%に低下している.（図 5 )

（3）指導区分からみた罹患状沉

図 5 に示す通り各年度とも要医療が高率で

裴 3 在学生結核羅患状沉

\begin{tabular}{|c|c|c|c|c|c|c|c|c|}
\hline \multirow{2}{*}{$\begin{array}{l}\text { 年 } \\
\text { 度 } \\
\text { 別 }\end{array}$} & \multirow{2}{*}{$\begin{array}{l}\text { 学在 } \\
\text { 籍 } \\
\text { 生数 }\end{array}$} & \multirow{2}{*}{$\begin{array}{l}\text { 絬総 } \\
\text { 核数 }\end{array}$} & \multirow{2}{*}{$\begin{array}{l}\text { 在百 } \\
\text { 籍分 } \\
\text { 者率 }\end{array}$} & \multicolumn{4}{|c|}{ 要 医 療 } & \multirow{2}{*}{$\begin{array}{l}\text { 要 } \\
\text { 観 } \\
\text { 祭 }\end{array}$} \\
\hline & & & & 話 & 入院 & $\begin{array}{l}\text { 㼭 } \\
\text { 休学 } \\
\end{array}$ & 要 服 & \\
\hline & 2480 & 55 & 2.21 & 41 & 6 & 13 & 22 & 14 \\
\hline 04 & 2706 & 53 & 1.98 & 35 & 2 & 14 & 19 & 18 \\
\hline & 2832 & 44 & 1.55 & 29 & 1 & 11 & 17 & 15 \\
\hline
\end{tabular}

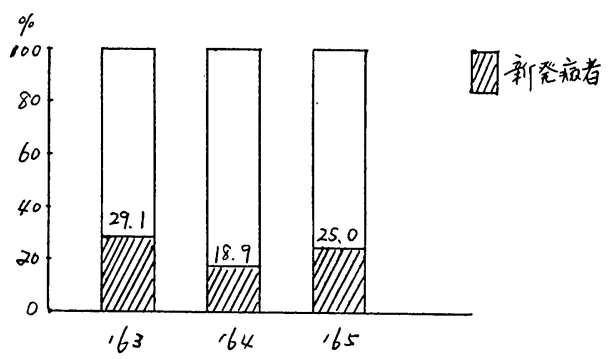

図 4 結核総数に新発病の占める梁
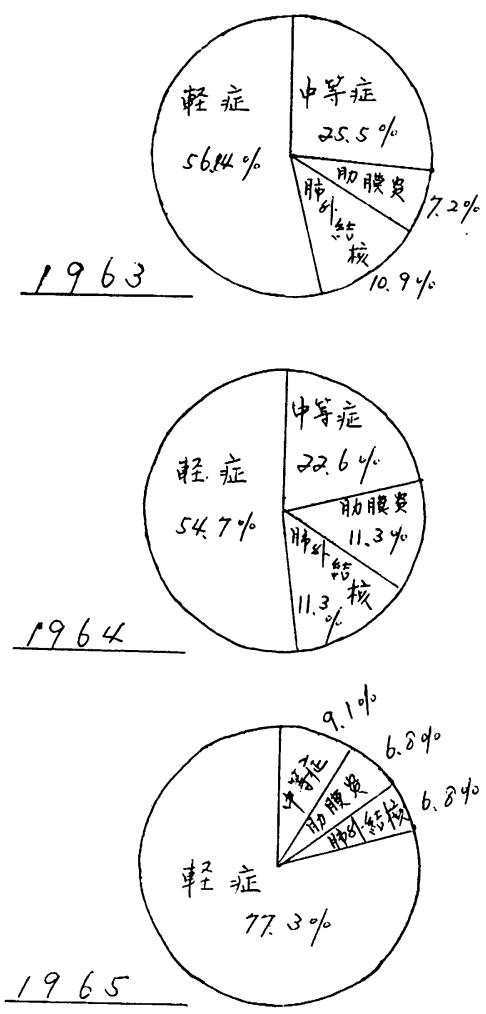

図 5 症状別による分類

即ら1963年 $74.5 \% ， 1964$ 年1965年には約 $8 \%$ の 減少をみせて扣り，また要観察は 1963 年 25.5 \%が最低率で 1964 年34\%，1965年34.1\%と殆 ぞ近似している，次に要医療を区分してみる と, 要服薬通学が第一位で 1963 年40\%が最高 で1965年38.6\%，1964年 35.8\%の順である. 要休学は1964年26.4\%，1965年25\%，1963 年 
$23.5 \%$ の順に少くなつている. 要入院は 1963 年10.9\%の高率であるが，1964年3.8\%1965年 $2.3 \%$ に激減している.

本学生の要医療を全沖縄 ${ }^{1)} 20$ 29才の要医 療と比较した場合，1963 年に於ては大学生が 1. $65 \%$ 沖縄1.67\%で近似しているが，1964 年
では大学生 $1.28 \%$, 沖縄1. 45\%でその差は 1.7 $\% ， 1965$ 年では大学生1.02\%沖縄1.34\%でそ の差 $3.2 \%$ となつ，次第に大学生が大きく低 率を示している. 又全国大学の在学生の結核 患者の占める率に比較すると ${ }^{2)}$, 本大学生は 約 2 倍以上の罹患率を占めている.（図 7 ）

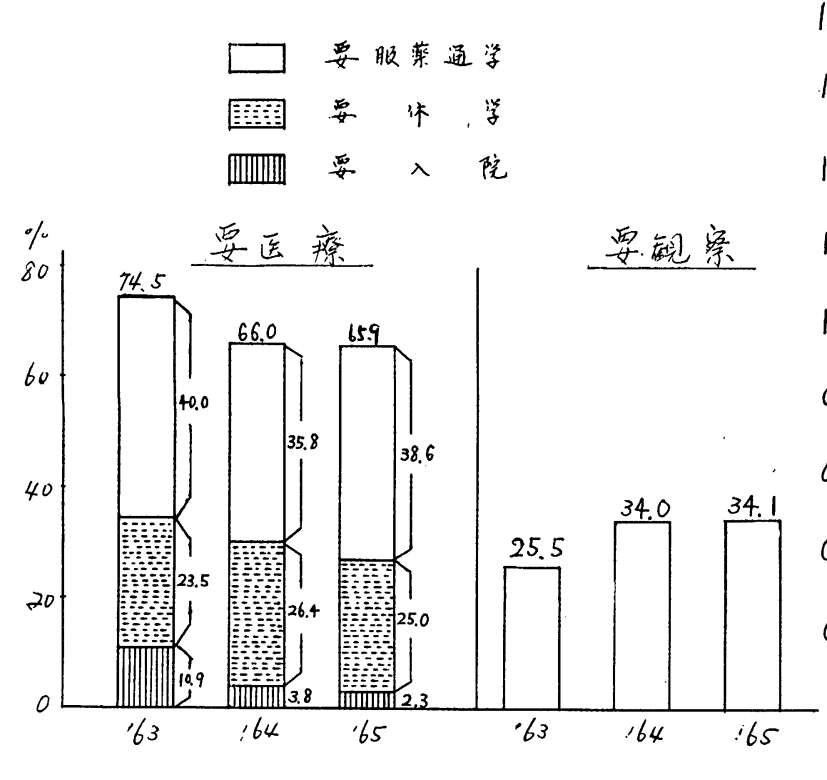

図 6 指導区分

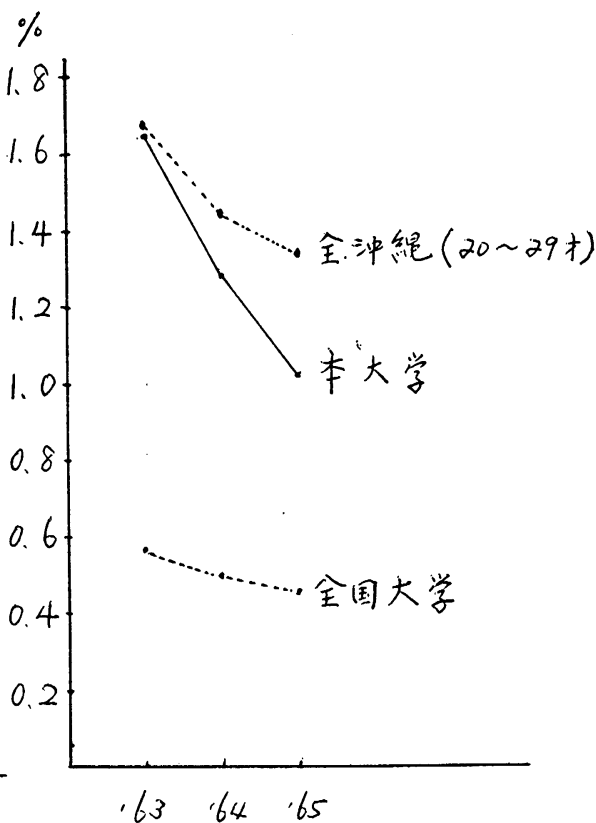

図 7 荘医療の比較
（4）出身地別にみた罹㭧状況

図 8 に示すごとく，各年度とも都市に多い 傾向であるが，農漁村との差は1963年0.37\%， 1964年 $0.13 \% ， 1965$ 年0.11\%と年々その差が 縮少しつつある.

B 結核による休学者及び退学者の推移 結核による休学者は表 4 に示す通り各年度 を通じて賃病休学者が第一位を占めて拉り， 漸次減少の傾向がみ.られるが30\%以上である。 これを 1964 年に於ける全国大学生 $23 \%{ }^{33}$ に比 較すると $20 \%$ も高率を示している.(図9) 結核 による退学者は1951年,1960年はいないがその
他の年度は1〜2名いる.しかし死亡退学者は各 年度とも皆無である。結核による休学時期は 1956 1960 年末では比較的 1 年， 4 年に多く みられたが，以後は 2 年， 3 年に多くなつた 傾向がみられる。（表 5 )

3. ツ反応

\section{(1) 受診状況}

年度別による受部状況は図 10 に示す通り 1957〜1959 年までは50\%以下で 1960～1963年 に上昇して75\%となり 1964～1965 年に於ては $80 \%$ 以上の受診率を示している。これを全国 大学に比較すると ${ }^{1)} 1960$ 年以前は全国大学よ 


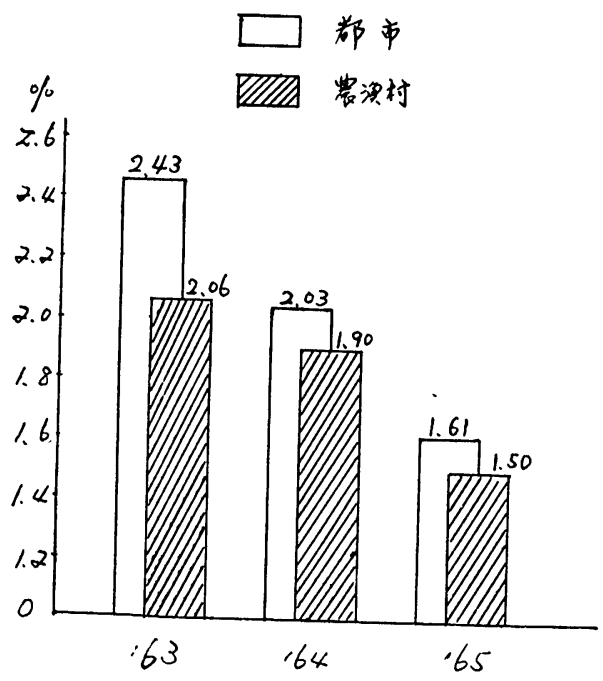

図 8 出身別による罹热状況

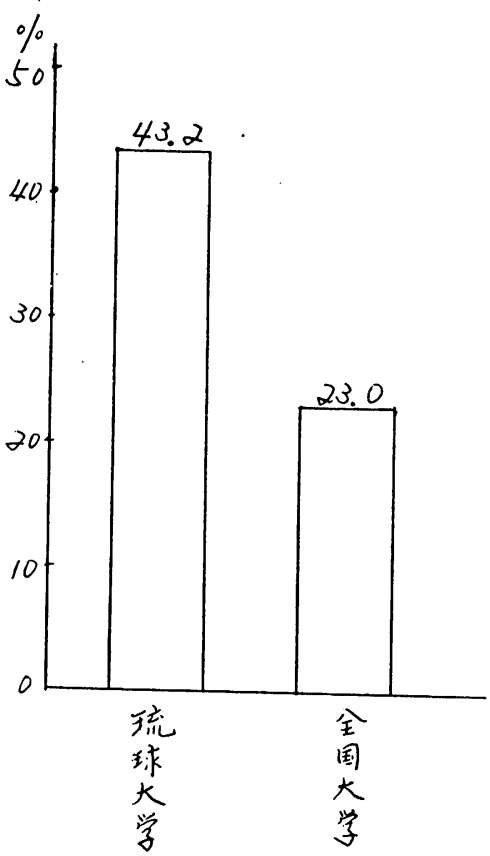

図 9 結核休学者の比較

り低率であつたが，以後はこれより高率を示 している.

（2）ツ反応検查の成績

年度別の推移をみるとツ反応陽性率は 1957
裴 4 結核による休学者及退学者の推移

\begin{tabular}{|c|c|c|c|c|c|c|}
\hline \multirow{2}{*}{$\begin{array}{l}\text { 年 } \\
\text { 度 } \\
\text { 別 }\end{array}$} & \multicolumn{3}{|c|}{ 第 病 休学者 } & \multicolumn{3}{|c|}{ 賃病退学者 } \\
\hline & $\begin{array}{l}\text { 休学 } \\
\text { 実数 }\end{array}$ & \begin{tabular}{|c|} 
\\
結核 \\
学者
\end{tabular} & $\%$ & $\begin{array}{l}\text { 退学 } \\
\text { 実数 }\end{array}$ & $\mid \begin{array}{c}\text { 結核 } \\
\text { 退学者 }\end{array}$ & $\%$ \\
\hline 1956 & 25 & 14 & 56.0 & 4 & 2 & 50.0 \\
\hline 1957 & 24 & 17 & 70.8 & 2 & 0 & 0 \\
\hline 1958 & 19 & 7 & 36.8 & 8 & 2 & 25.0 \\
\hline 1959 & 31 & 14 & 45.2 & 5 & 1 & 20.0 \\
\hline 1960 & 21 & 8 & 38.1 & 6 & 0 & 0 \\
\hline 1961 & 20 & 7 & 35.0 & 4 & 1 & 25.0 \\
\hline 1962 & 30 & 11 & 36.7 & 1 & 0 & 0 \\
\hline 1963 & 49 & 18 & 36.7 & 1 & 1 & 100 \\
\hline 1964 & 39 & 17 & 43.0 & 11 & 2 & 18.2 \\
\hline 1965 & 40 & 13 & 32.5 & 6 & 2 & 33.3 \\
\hline
\end{tabular}

表 5 結核休学の時期

\begin{tabular}{l|l|l|l|l|l}
\hline 年 & 学年 & 1 年 & 2 年 & 3 年 & 4 年 \\
\hline 1956 & 4 & 2 & 5 & 3 \\
1957 & 6 & 5 & 2 & 4 \\
1958 & 1 & 0 & 2 & 4 \\
1959 & 8 & 2 & 1 & 3 \\
1960 & 6 & 1 & 1 & 0 \\
1961 & 2 & 1 & 3 & 1 \\
1962 & 2 & 2 & 6 & 1 \\
1963 & 2 & 4 & 7 & 5 \\
1964 & 2 & 4 & 9 & 2 \\
1965 & 2 & 3 & 5 & 3 \\
\hline
\end{tabular}

年 $51.2 \%$ 最高率に，以後 1963 年までは $45 \%$ 以上であつたが1964年 $42 \% ， 1965$ 年40.4\%に 低下の傾问がみられる。疑陽性率は1956〜1961 年までは3.1〜6.1\%間であつたが，1962 年以 後は上昇の傾向がみられる。陰性率は 1965 年52.3\%が最高率を示し， 1962 年 $42.8 \%$ を最 低率とした間の成績である。（表 6)

本大学生の陽性率を 1964 年に於ける沖䋲の 結核の現状から比較すると ${ }^{4)}$ 図 11 に示す通り 小学生 $0.67 \%$, 中学生 $12.7 \%$. 高校生 $18.5 \%$. 一般 $34.3 \%$ で，また 1963年に全沖䋲の 20〜24 才の $43.4 \%$ であるが本学生は高校生より約 $23.5 \%$ 一般より $7.7 \%$ 多いが，20２4才とは近 
表 6 ツ反応検査成績の推移

(\%)

\begin{tabular}{c|c|c|c|c}
\hline 年 度 別 & 検查人員 & 陽 性 & 疑陽性 & 陰 性 \\
\hline 1956 & 689 & 49.8 & 4.1 & 46.0 \\
1957 & 1167 & 51.2 & 4.3 & 44.5 \\
1958 & 1490 & 45.0 & 3.1 & 51.9 \\
1959 & 2095 & 44.7 & 5.0 & 50.3 \\
1960 & 2303 & 45.9 & 6.2 & 47.9 \\
1961 & 2349 & 47.8 & 5.3 & 46.9 \\
1962 & 2372 & 42.8 & 9.0 & 42.8 \\
1963 & 2407 & 47.6 & 7.6 & 44.8 \\
1964 & 2612 & 42.0 & 8.0 & 50.0 \\
1965 & 2695 & 40.4 & 7.3 & 52.3 \\
\hline
\end{tabular}

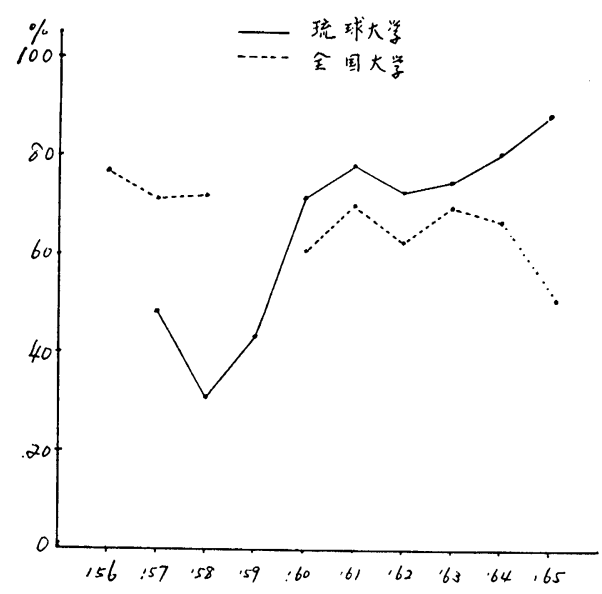

図 10 ッ反応受診の推移

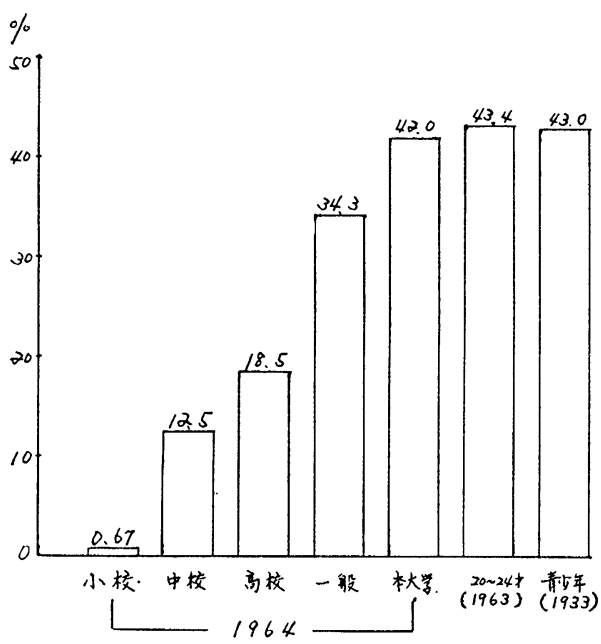

図 11 ッ反応陽性率の比較
似を示している. 又 1933 年5) に於ける沖縄青 少年 $43 \%$ と大差はみられない。

\section{（3） ッ反陽転率の推移}

年度別による在学生の陽転率は図 12 に示す 通り 1 ケ年間に1958年を除いては 1961 年まで は3〜 4\% の増加率であつたが，以後は漸次減 少の傾向をみせ $2 \%$ 内外の增加率である. 入学 年度別による入学者の進学に伴う陽性率は表 7 に示す通り，各年度によつて差異があるが 概して 3 年, 2 年に多い傾向がみられる.

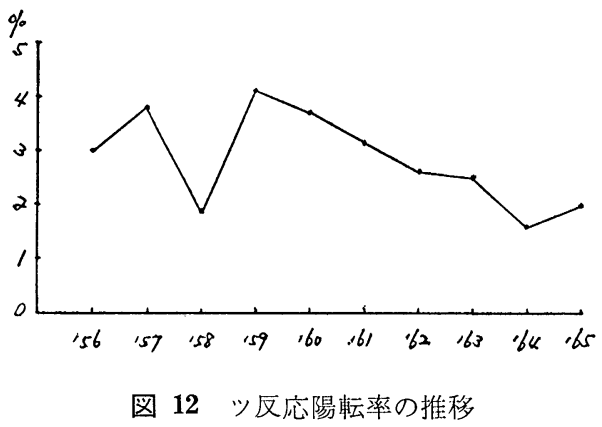

表 7 入学年度別進学に伴らッ反応陽転率

\begin{tabular}{c|c|c|c|c}
\hline $\begin{array}{c}\text { 入年度別 } \\
\text { 学 }\end{array}$ & $\begin{array}{c}\text { 反学陰性者 } \\
\text { 年 }\end{array}$ & 2 年 & 3 年 & 4 年 \\
\hline 1956 & 217 & 0.5 & 6.0 & 1.8 \\
1957 & 249 & 4.5 & 0.8 & 0.8 \\
1958 & 275 & 2.9 & 6.5 & 1.1 \\
1959 & 331 & 2.4 & 2.7 & 4.2 \\
1960 & 225 & 2.2 & 10.2 & 1.8 \\
1961 & 227 & 1.8 & 1.3 & 0.4 \\
1962 & 280 & 1.8 & 2.5 & 2.9 \\
4963 & 346 & 2.0 & 1.7 & 0.9 \\
1964 & 475 & 1.9 & 1.5 & \\
1965 & 459 & 3.7 & & \\
\hline
\end{tabular}

（4）出身地別によるツ反応陽性率

在学生の場合都市と農漁村を比較すると 1960 年に於ては都市 $44.6 \%$ 農漁村 $35.7 \%$ で都 市が8.9\%多い。之を 5 年後1965年に於ては都 市 $39.3 \%$ ，農漁村 $35.2 \%$ で4.1\%都市が多くそ の差は $2 / 1$ に縮少している. 又年度別入学者の 場合は都市に於ては漸次減少の傾向を示して 


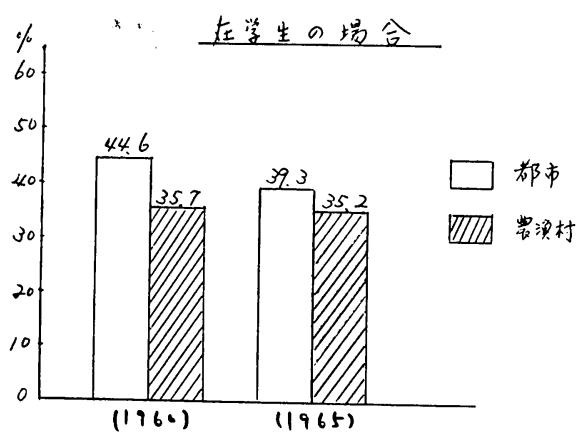

50〜70\%を占める傾问になそた。既往歷の中 には 1962，1962年各 1 名，1964年 3 名の肺外 科手術者も入学しているが，症状として中等 症の 既往者が多くなつたことを示している. 既往歴を有する者が90\%以上，高校，中等期 で罹㭧しているので再発の扣それもあるが今 のところない。罹禹中の入学者も漸次增加の 傾向があり，特に 1964年に於ては 既往歴より 高率を示しており，次第に既往歴と其の差が 縮少しつつある。一方入学後の 経過状況から みると服薬通学者が多いが最近休学者も多く なりつつあることは注目すべきである。

1964 年に沖䋥に於ける結核実態調査による と,0〜9才 $0.3 \sim 0.4 \%$.10〜19才0.7〜0.8\%の 肺結核要医療者がいるが,之に比較すると本大 学入学前の罹息率は可成り多いものと推測さ れ，この様な現象は大学受験者には多数の既 往歴や発病者がいると思れ，受験者に対する 結核対策が十分になされていないと考光たい。 従つて，受験生の健康管理は勿論であるが,

図 13 出身地別のツ反応陽性率の推移在学生の 場合(上図) と年度別入学者の場合(下図)

いるが，鿊漁村の場合は余り変動なく都市の 減少によつてその差は縮少している，すなわ 台1956年に於て15.9\%の差は1965年では0.8\% となつた。（図13）

\section{考案}

琉球の大学に於ける健康管理は不十分な点 が多く，従つて大学生の結核の奏態関する 調査資料も少い，著者は本大学に於てこの 3 年来，結核管理に主力を扣いて其の実態を明 らかにすべく努力をかさねたが，沖繩の結核 の現状からみると今後大学生の結核対策の在 り方に検討する必要があると思い，之を疫学 的な見地から本研究を試みた。

1. 入学前の結核羅患状沉について

罹患率は年々增加し 正確に近い調査による と思われるが， 1963 年以後は急增の倾向がみ られる。また，症状別分類でも漸次肺結核が 既往歷からの結核の再発防止，罹病者の入学 洔の敩重なる 精密検査によつて入学させ，ま た罹患中入学者の経過推察に対しても十分な る健康管理が必要である。

2. 在学生の結核の現状について

比較的調査資料の揄つた1963〜1965年の3年 間の推移をみると学生検晾の強化, 沖縄の結 核刘策の進歩や，また結核㭧者の卒業，新発 生者の減少等が相まつて比較的急下降に罹患 率の低下をみせた。 また症状別分類から観察 してみた場合，1963，1964に於ては大差はな いが 1965 年に至つては著しい変化をみせた。 即占，1963，1964年では軽症が1/2，中等症が $4 / 1$ 占めていたが 1965 年には軽症が $4 / 2$ 以上 に增加し中等症が1/10に低下を示した・之を沖

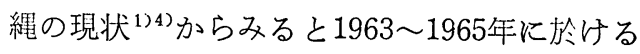
軽症は59.7\% 62\%, 中等症は $29.5 \%$ 22.6\% で大きな差異は認められず横逼いの状況であ る・かように本大学生の結核は比較的急減少を 示しているが 沖縄の結核横這い状況や1963年 
に於ける沖縄の児童生徒の在宅及び入院患者, 即ち小学生 $0.43 \%$,中学生 $0.50 \%$, 高校生 2.12 \%からみると本学生の感染機会は多く又,発病 者も出る可能性は十分あると思われる.次に要 医療の 区分からみると依然として要医療が60 \%を占めているが, 年々要入院, 要休学の減 少の傾向があることは本大学の結核対策の強 化の結果とみてよいだろう。結核罹患率の減 少を沮む一因として旧結核患者がある。すな わち本大学に於ては旧結核患者が新発生者よ り3〜4倍も多いことは旧結核患者の療養期間 が長時間を示すものであり, 今後検診の強化 によつて早期発見を要する。一般に結核は都 市に多い傾向がある ${ }^{6)}$. 本大学生でも其の傾向 はみられるが，年々農漁村との差が非常に縮 少する傾向がみられる. これは学生生活が広 範囲に亘つているのも一因と思われる。

3. 結核による休退学者の推移について

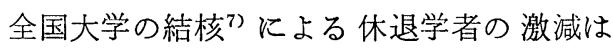
学校検診の効果にもよるが, 国民全体の結核対 策が奏効したことを示している。これに比べ本 大学生の休退学者の漸次減少したことは云兄, 未だ，休学者は傷病休学者の第1位で $30 \%$ 以上 を占めている.これは学生の健康管理の不十分 と沖縄に於ける結核対策の不徹底さを示して いるとみてよい，また，結核休学者が 1956〜 1962年までは比較的 1 年, 4 年に多かつたが, 以後 2 年, 3 年に変動しつつあることは今後注 目すべきことであると考えたい，

4. シ反応の陽転状況について

ッ反応と自然陽性は結核の罍延状況を知る 一つとして価值あるものである，本大学生 ${ }^{2)}$ は既往に BCG 未接種により，全員自然陽性 者であるので感染率を知るには好都合である。 大学生のッ反応の推移をみると，陽性率は潮 次減少をみせ。また 1 ケ年間に於ける陽転率 も同様に 減少の傾向がみられるが，陽性率の 低下は必ずしも患者が減少するとは限らない のである.ッ反応陽性率を本土大学生と比較す ることは困難であるが約 $1 / 2$ 以下であり，1963
年の府県別青少年 ${ }^{5)}$ の陽性率の 高率県に位し ている.また1963年に於ける全沖縄 20〜24 才 と近似している.

入学者の進学に伴う陽性率は 2 年, 3 年に多 い傾向を示しているが，これは前述の休学者の 時間と後述する 新発生時期と一致しているこ とは，これらの間に関係があり，今後その要 因を究明する必要があると考えたい.結核の感 染率は結核患者発病と同様に都市に多いのが 通例であるが，云うまでもなく感染率を左右 する大きな要因は感染機会の大小によるもの で, 大学生の場合は全く前述の結核罹患者と 同様漸次都市と農漁村との差異が縮少しつつ ある. BCGに関する発病との関連における文 献は既に多くの研究者によつて報告されてお ると郝りであるが，沖縄に於ても関心事の一 つである.しかし，現在 BCG 接種は未だ試 験的段階にとどまつて拈り, 今後本大学生に しても発病の予防の一環として実施の可否は 今後の残された問題の一つであろう.

\section{結論}

琉球大学生の 10 年間の結核調査概要の結論 は次の通りである.

1. 入学前の 結核罹患状況: 結核既往歴及 び罹患中入学者が年々増加の傾向があり症状 別では肺結核が最も多い，罹患中入学者の経 過状況は服薬通学が多いが, しかし最近休学 する者も多くなる傾向がある.

2. 在学生の結㤥罹患状況: 3年間の推移を みると漸次減少している. 症状別では 1965 年 に於ては中等症が激減し軽症が多くなり，指 導区分では要医療が多いが次第に要入院, 要 休学は減少しつつある. 結核患者総数は旧結 核患者が70〜80\%を占めている. 出身別では 都市が多いが年々農漁村とその差は縮少の現 象がみられる.本大学生の結核䍜患状況は沖縄 の結核罹患状況に比較すると目立つて減少の 傾向を示しているが,未だ全国大学の平均值に は及ばない,結核による休退学者も漸次減少し 
ているが依然として傷病休学者の第 1 位を占 め30\%以上の比率である.

3. ッ反応：受診率の 1960 年以後の上昇か らみて結核に対する関心が高まつたことを示 す. ッ反応の成績は陽性率の減少, 疑陽性率 の增加, 陰性率の增加の傾向がある. 1年間に 於ける陽性率も漸次減少の傾向がみられ，そ の時期も3年， 2 年に多くなりつつある. 出身 別では結核䍜患状況と全く同じ様な現象がみ られる。

終りに本研究に留篤な御指導を賜つた柳沢文徳教 授に深謝すると共に，調查資料に御協力いただいた 琉球大学医務室職員, 学生部職員, 並びに那羁保健
所医師, 公象衛生看護妒, 那䩗病院医師, 結核予防 協会職員の方々に感謝の意を表します.

\section{主な文献}

1) 琉球政府厚生局：結核の現状（1963～1964）

2) 交部省：学校保健統計調查報告書（昭40）

3) 交部省大学学術局：大学に於ける保健管理に 関する実態 (昭40)

4）琉球政府厚生局：結核の現状（1962～1963）

5) 有馬陽一：鹿児島大学医学雑誌，10,175（昭 34)

6）結核予防協会：疫学的立場よりみたッ反忘の 話 (1960)

7) 御園生圭輔：学校保健研究，8，13号 (1966) 